\title{
Challenges and Solutions in Management Accounting - Implementation of Target Costing in the Industry of Equipment Production
}

\author{
Violeta Maria Isai ${ }^{\star}$, Cristina Geru ${ }^{\star \star}$
}

\begin{tabular}{l}
\hline \multicolumn{1}{c}{ A R T I C L E I N F O } \\
\hline Article history: \\
Accepted November 2020 \\
Available online December 2020 \\
\hline JEL Classification \\
L16, L60 \\
Keywords: \\
Target price, Profit margin, Target \\
cost, Target cost index
\end{tabular}

A B S T R A C T

Target costing management, although it has been around for a long time, has only recently attracted the attention of companies. Its adoption was imposed by the intense competition that characterizes today's markets. Nowadays it is imperative for the companies to get involved in setting the costs of products and services in a more active and aggressive way from one year to the next. The purpose of the research in the present study is the analysis of the possibilities of implementing this method within the car manufacturing companies. Two research directions were pursued: a conceptual one, through the contribution brought to the increase of the knowledge of the managerial accounting and of the way of its organization and a practical one, by accessing and respectively the modernization of the cost calculation methodology in the mentioned sector.

(C) 2020 EAI. All rights reserved.

\section{Appreciations on the method}

"A European manager uses cost information to make pricing decisions, while a Japanese manager uses price information to control costs." (T. Tanaka, Target-Costing at Toyota). "The goal of every company should be to reduce costs in the design phase and act right from the start." (Bruce Hollingsworth, Owner of Purchasing Solutions, Oregon). "Every design decision must be based on whether the customer wants to pay for this feature" (Pete Zampino, CAM-I manager). These are just some of the many positive references to the target costing method which, if applied correctly, can provide multiple benefits to any business, making it possible to reduce costs by $20-30 \%$, depending on the product and market conditions. Target costing is a vision that differs fundamentally from the traditional way of looking at costs and prices. The fundamental equation of the "price - profit margin = cost" method highlights that prices are driven by the market or the company, which reduces prices to increase market penetration; the profit margin is thus established so that the company can obtain income, and the costs are determined according to the prices and the profit margin. Target costing leads a product development strategy, in which the design team focuses on the end user and on real market opportunities. This rigorous cost-cutting and management technique helps prevent the launch of low-margin products that do not generate adequate revenue for the company, but its greatest value lies in bringing market challenges to designers through the production chain. The logic of the method is very simple. Taking a look at the future markets, the company establishes the customer segments and takes into account the most attractive ones, after which it determines what level of quality and functionality the product will reach in each segment, given a determined target price. Following is the design of the supply, manufacturing and distribution processes that will allow obtaining the desired profit for this target. By applying the method, the company starts from the requirements of customers and their ability to pay, instead of following the traditional practice of calculating prices based on costs. Target-costing is an approach aimed at the functional analysis of the value-price-benefit-cost ratio. Target costs are based on the rule that the market is the one that dictates the selling prices and not the costs of the company. Thus, for a product to be profitable, it must go from the price to the target cost. Sales prices must ensure full cost coverage and a share of profit. Thus, the general equation of the target costs is:

The selling price - desired margin $=$ the full target cost

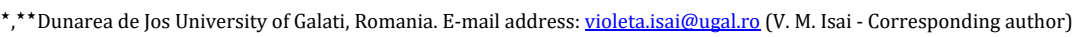




\section{Possibilities of implementation and application}

We conducted the research on a product specific to the industry of equipment production"Hydraulic mould"- and modelled the application of the target costing method to calculate the costs of this product.

The technological process through which the product is obtained is organized in flow as follows: cutting sheets, profiles, pipes; forging of forged and cast parts; welding assembly; detensioning in the oven; blasting; priming; mechanical processing of parts and subassemblies; hydraulic and electrical assembly; house samples; possible adjustments, adjustments, setting in parameters; removal; conservation; loading on the means of transport.

Customers who purchase these products are companies with a metallurgical profile that have sections for plastic deformation (forging) or cold pressing. The main requirements of the customers regarding the product are to correspond to the required characteristics (pressing force, mass dimensions, stroke, etc.); to be as reliable as possible; to have a low purchase price; to ensure technical assistance and spare parts by the manufacturer, on time and of quality. The product meets these requirements, the main issues that are still negotiated are the sale price and delivery time. These two aspects lead to the loss of contracts to competitors in countries with an advanced economy. The market price of the press is about 26,000 lei, and its current cost to the producer is 18,616.31 lei, being composed of direct expenses (raw materials, materials, collaborations and labour of direct workers) about $60 \%$ and indirect expenses (section directors and general directors) about $40 \%$. The current profit is 11,000 lei.

The product can be broken down into the following subsystems, with the related costs: metal structure 12,516.31 lei; electrical installation 2,500.00 lei, hydraulic installation 3,600.00 lei.

In order to face the competition, the companies resorted to the following measures: cost planning, which includes the target costing method; regular cost reporting; budgeting systems; long-term business plans. In order to be able to sell its products, the company must reduce its prices in order to reach the level of market prices. Thus, the target price of the product will be 26,000 lei, given that the company wants to maintain the same level of profit, so the target profit will be 11,000 lei. By subtracting the target profit from the target price, a target cost of 15,000.00 lei will result. In order to achieve these cost reductions, the company conducted a market study which identified the functions of the product that are most appreciated by customers: aesthetics, functionality and strength structure, achieving the decomposition of the product according to these criteria. The functions are appreciated with different percentages in the overall utility of the product, after which these percentages are transposed into values, as shown in the following table:

\begin{tabular}{|l|r|r|}
\hline \multicolumn{1}{|c|}{ Functions } & Percentage (\%) & \multicolumn{1}{c|}{ Value (Lei) } \\
\hline Aesthetics & $8 \%$ & $1,200.00$ \\
\hline Functionality & $17 \%$ & $2,550.00$ \\
\hline Strength structure & $75 \%$ & $11,250.00$ \\
\hline Total & $100 \%$ & $15,000.00$ \\
\hline
\end{tabular}

Knowing the value of these features does not provide enough information to the design team and suppliers. To create more accurate targets, designers use to define how the various components of the press contribute to achieving the functional requirements expressed by customers. Subsequently, the extent to which the components of the product contribute to the performance of its functions is established. To achieve this, a table that contains the product components horizontally is drawn up, and its functions appreciated by customers vertically, and the design team, comparing the functional requirements with the product components, allocates different percentages, depending on the contribution of each component to the achievement of the functional requirements, as shown in the following table:

\begin{tabular}{|l|r|r|r|c|}
\hline & \multicolumn{1}{|c|}{ Aesthetics } & Functionality & Strength structure & Total Lei \\
\hline Value & $1,200.00$ & $2,550.00$ & $11,250.00$ & $15,000.00$ \\
\hline Metallic structure & $26 \%$ & $21 \%$ & $53 \%$ & \\
\hline Hydraulic installation & $34 \%$ & $31 \%$ & $34 \%$ & \\
\hline Electrical installation & $40 \%$ & $48 \%$ & $13 \%$ & \\
\hline Total & $100 \%$ & $100 \%$ & $100 \%$ & \\
\hline
\end{tabular}


The next step is to calculate the target cost for each component, depending on its contribution to the performance of functions appreciated by customers. In this sense, the partial value of each function is multiplied by the contribution that the different components bring to its realization. The sum of these multiplications generates the target cost of each component, as shown in the table below:

\begin{tabular}{|l|r|r|r|r|}
\hline & \multicolumn{1}{|c|}{ Aesthetics } & Functionality & Strength structure & Target Cost \\
\hline Value & $1,200.00$ & $2,550.00$ & $11,250.00$ & $15,000.00$ \\
\hline Metallic structure & 312.00 & 535.50 & $5,962.50$ & $6,810.00$ \\
\hline Hydraulic installation & 408.00 & 790.50 & $3,825.00$ & $5,023.50$ \\
\hline Electrical installation & 480.00 & $1,224.00$ & $1,462.50$ & $3,166.50$ \\
\hline Total & $1,200.00$ & $2,550.00$ & $22,500.00$ & $15,000.00$ \\
\hline
\end{tabular}

In the next step, the target costs of the components will be compared to their estimated cost, establishing the differences between the estimated costs and the target costs of the components.

\begin{tabular}{|l|r|r|r|}
\hline & Estimated Cost & \multicolumn{1}{c|}{ Target Cost } & \multicolumn{1}{c|}{ Cost difference } \\
\hline Metallic structure & $12,516.31$ & $6,810.00$ & $+5,706.31$ \\
\hline $\begin{array}{l}\text { Hydraulic } \\
\text { installation }\end{array}$ & $3,600.00$ & $5,023.50$ & $-1,423.50$ \\
\hline $\begin{array}{l}\text { Electrical } \\
\text { installation }\end{array}$ & $2,500.00$ & $3,166.50$ & -666.50 \\
\hline Total & $18,616.31$ & $15,000.00$ & $+3,616.31$ \\
\hline
\end{tabular}

As it results from this analysis, the target costs of the Hydraulic Installation and the Electrical Installation were estimated above the market price, and the metallic structure is below the estimated cost. In order to reach the target cost, action must be taken on the components that have been exceeded.

In support of this analysis, one can also calculate the target cost index, which expresses the relationship between the percentage of components in performing functions and the percentage of components within the costs. To obtain this index, the following steps are followed:

1. The product is decomposed into its functions appreciated by customers, in a similar way: Aesthetics $8 \%$; Functionality 17\%; 75\% Strength Structure; Total 100\%.

2. The extent to which the components of the product contribute to the performance of the functions shall be established:

\begin{tabular}{|l|r|r|r|r|}
\hline & \multicolumn{1}{|c|}{ Aesthetics } & Functionality & Strength structure & Total \\
\hline Percentage & $8 \%$ & $17 \%$ & $75 \%$ & $15,000.00$ \\
\hline Metallic structure & $26 \%$ & $21 \%$ & $53 \%$ & \\
\hline Hydraulic installation & $34 \%$ & $31 \%$ & $34 \%$ & \\
\hline Electric installation & $40 \%$ & $48 \%$ & $13 \%$ & \\
\hline Total & $100 \%$ & $100 \%$ & $100 \%$ & \\
\hline
\end{tabular}

3. The percentage importance associated to each component is established, multiplying the partial percentage of each function with the contributions that the different components bring to its accomplishment:

\begin{tabular}{|l|r|r|r|r|}
\hline & \multicolumn{1}{|c|}{ Aesthetics } & Functionality & Strength structure & \multicolumn{1}{c|}{ Total } \\
\hline Percentage & $8 \%$ & $17 \%$ & $75 \%$ & $100 \%$ \\
\hline Metallic structure & $2.08 \%$ & $3.57 \%$ & $39.75 \%$ & $45.40 \%$ \\
\hline Hydraulic installation & $2.72 \%$ & $5.27 \%$ & $25.50 \%$ & $33.49 \%$ \\
\hline
\end{tabular}




\begin{tabular}{|l|r|r|r|r|}
\hline Electrical installation & $3.20 \%$ & $8.16 \%$ & $9.75 \%$ & $21.11 \%$ \\
\hline
\end{tabular}

4. The analysis of the costs and of the percentage importance associated to each component in the accomplishment of the functions is performed:

\begin{tabular}{|l|r|r|r|r|}
\hline \multicolumn{1}{|c|}{ Components } & Estimated Cost & Cost Percentage & \multicolumn{1}{c|}{$\begin{array}{c}\text { Components } \\
\text { Percentage }\end{array}$} & Target Cost Index \\
\hline $\begin{array}{l}\text { Metallic } \\
\text { structure }\end{array}$ & $12,516.31$ & & & \\
\hline $\begin{array}{l}\text { Hydraulic } \\
\text { installation }\end{array}$ & $3,600.00$ & $19.34 \%$ & $33.49 \%$ & $1.73 \%$ \\
\hline $\begin{array}{l}\text { Electrical } \\
\text { installation }\end{array}$ & $2,500.00$ & $13.43 \%$ & $21.11 \%$ & $1.57 \%$ \\
\hline Total & $18,616.31$ & $100 \%$ & $100 \%$ & \\
\hline
\end{tabular}

The significance of the target cost index can be interpreted as follows:

* if the index is less than 1, the components are too expensive from the customer's point of view, because the functions become achievable only at the value of 1 ; if the index is higher than 1 , it means that the customer puts too much price on the functions performed by the components, and the company must mobilize to find ways to improve the function.

This analysis shows that the metallic structure is too expensive from the customer's point of view, and the electrical and hydraulic installation are overestimated. This overestimation also results from the fact that the upgrades requested by the customers refer only to these two components.

\section{Research results}

Based on the results of the two analyses (which actually indicate the same thing), the company must look for ways to reduce the cost of the metallic structure. For this, a multifunctional team was formed, which established the following cost reduction solutions:

$\$$ Negotiation with direct suppliers of raw materials and materials (metal sheets, castings and forgings, etc.), which can lead to a discount of up to $10 \%$, representing 1,200 lei according to the market prices in the analysed period.

* Decreasing the net weight of the machine by up to $5 \%$, by designing more supple shapes, but which can withstand the demands imposed, can lead to a saving of 10 tons (approximately 500 lei).

* Reduction of the degree of processing by using welded constructions instead of cast and forged parts, but it has a lower percentage in cost reduction efforts, reaching up to 8\% (about 800 lei).

* Reduction of costs by internal organization, reduction of stagnation times, waiting times, use of processing regimes with high-performance tools, organization of work on technological flow (processing line), reduction of the number of manipulations, reduction of processing additions, automatic welding and so on can contribute to reduction of costs by up to 7\% (max. 1,116 lei).

Through all these cost reductions, the company reached the level of the target cost, managing to reduce the costs by 3,616.31 lei for the metallic structure.

The study shows, among other things, that, customers overestimate the other two components (electrical installation and hydraulic installation), being willing to pay even more for them; in this case, the company must mobilize to find ways to improve them. The modernization of the electrical and hydraulic installations is very opportune, but the production not being assimilated (they are received through collaboration) cannot be acted upon. However, there would be a possibility to modernize the facilities following the collaboration between the company's designers and those of the suppliers, who will unite their efforts to find the best opportunities to modernize them.

\section{Conclusions}

The purpose of the Target Costing method is to ensure adequate profits through simultaneous profit and cost planning. In achieving this goal, the basic characteristics of the method have a special importance, which are the following: it is a market-oriented calculation method, where the target costs are established by first determining the competitive market price, from which the profit rate is deducted; it is a customeroriented calculation method, which means that cost analysis focuses on customer requirements for quality, product sales price and delivery time (target cost must not only achieve the target profit, but also maintain the competitive dimensions of the product); it is a project-oriented calculation method (product design is the key to cost reduction efforts, knowing that $70-80 \%$ of costs are incurred at the design stage, although only $10-$ $20 \%$ of costs are consumed at this stage; at the design stage, it eliminates costly features and minimizes the need for further changes after production begins); it uses multifunctional teams, consisting of design and 
manufacturing engineers, sales and marketing representatives, materials supply, accountants and service representatives, who are unanimously responsible for obtaining the target cost; is a calculation method oriented towards the product life cycle; it involves the entire value chain, consisting of suppliers, distributors, service, which helps reduce costs (the system involves an active collaborative relationship, where cost reduction techniques are used by all members involved).

The listed characteristics distinguish the target costing method from the traditional methods. The latter start from the cost, to which is added the rate of profit to obtain the market price. If the market does not want to pay this price, then the company is trying to reduce costs. Target costing starts from the market price and a planned rate of profit, establishing an allowable cost.

\section{References}

1. Burrows G, Chancall R.H. - Target costing: first and second comings, Accounting History Review, 2012

2. Cooper\&Slagmulder - Target Costing and Value Engineering, Productivity Press, Portland, 1997

3. Clifton, Bird, Albano\&Townsend - Target Costing; Market Driven Product Design, Marcel Dekker Inc., 2004

4. Ebbeken Klaus, Possler Ladislau, Ristea Mihai - Calculaţia şi managementul costurilor, Editura Teora, 2000

5. Institute of Management Accounts - Implementing Target Costing, Canada, 1994

6. Jacomit A.M., Granja A.D.,Picchi F.A.- Target Costing research analysis: reflections for construction industry implementation, Manchester, 2008

7. Lee H.W. - Application of Target Value Design to Energy Efficiency Investments, UC Berkeley,2012

8. Sakurai Michiharu - Target Costing and how to use it, Journal of Cost Management, 1989

9. Tanaka Takao - Target Costing at Toyota, Journal of Cost Management, 1993 